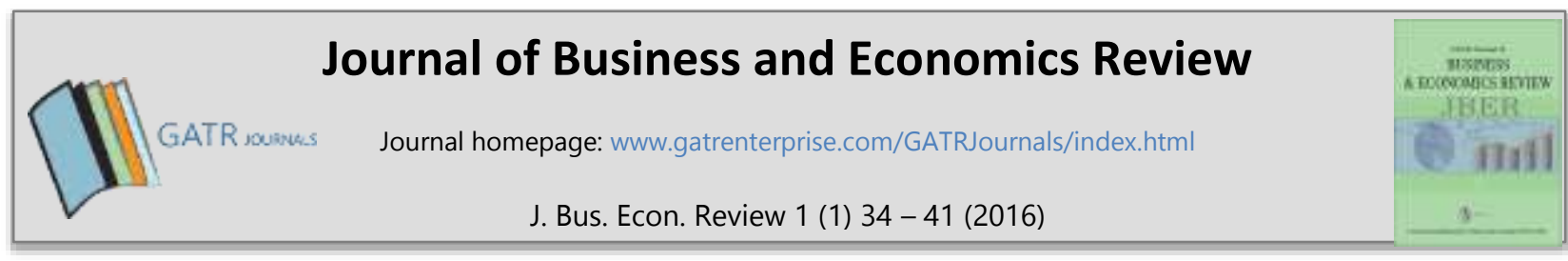

\title{
Accounting Students' Perceptions of AEC 2015 on Public Accounting Profession
}

\author{
Mirna Dianita ${ }^{1 *}$ and Niki Hadian ${ }^{2}$ \\ 1,2 Widyatama University, Jl. Cikutra No. 204 A, Bandung 40236 Indonesia
}

\begin{abstract}
Objective - The economic growth of a country is very important because it reflects the country's economic development and success. This study's objective is to examine how accounting students' perceptions of the public accounting profession are taken into account in facing the AEC 2015. In that regard, this study gauges how Indonesian companies can fulfil their needs to be more competitive in meeting the goals of the AEC 2015.

Methodology/Technique - This study is qualitative in nature thus analysis will be descriptive. Questionnaires were distributed to currently active students of accounting in Indonesia. The samples were extracted from a nonprobability sampling technique. The 339 respondents were selected based on a set of basic considerations. In this context, the participants must have knowledge of the AEC 2015 and are currently studying in public accountancy as a profession All were from Indonesia.

Findings - Results drawn from the respondents indicate that they do not deeply understand the description of the AEC 2015.Majority of the respondents (27.4\%) understood that the implementation of the AEC 2015 will make goods and services flow freely and majority $(39.8 \%$ ) also feel that they have a good ability in speaking with almost half of them assuming that they also write well in English. With regards to their competence in accounting after graduation, more than half $(52.2 \%)$ of the respondents agree that the competence of public accountants from the host country will not be able to compete with those from ASEAN countries.

Novelty - This paper enables accounting students to understand the challenges they face ahead, especially for those who are prospective successors to the Indonesian nation.
\end{abstract}

Type of Paper: Empirical

Keywords: AEC 2015; Public Accounting Profession; Accounting; Accounting Students Perceptions.

JEL Classification: M41, P46.

\section{Introduction}

The economic growth of a country is a very important thing. Every country in the world wants a change process so as to be able to achieve a better economy because a better economy is an indicator of a country's economic development and success. To achieve this, a country has to start from internal reforming economic conditions so as to be able to carry out international cooperations in all areas of trade. This, if done well, can

\footnotetext{
* Paper Info: Received: October 9, 2016

Accepted: December 27, 2016

* Corresponding author:

E-mail: mirna.dianita@widyatama.ac.id

Affiliation: Economics Department, Widyatama University, Indonesia
} 
contribute positively to its economic growth. There are several factors that can affect a country's economic growth, namely: human factor, natural resources factor, science and technology factor, cultural factor and capital factor. Taking Indonesia as an example, it is obvious that among these five factors, some have not been optimized y the government. To encourage and increase economic growth, Indonesia and nine other Asian countries formed the ASEAN Community in 2015, also called the ASEAN Economic Community 2015. Its goal is to enable all these countries to be competitive in terms of trade and commerce.

In order to enable the companies in Indonesia to be more competitive in facing the AEC 2015, professionals from various fields such as professional accountants and auditors need to be involved. The public accounting profession is one of the professions that are needed for the purpose of generating an implementation of public accountability which can create implications for the effective prevention of corruption or other irregularities. Given this profession, it is undeniable that most public accountants deal with good corporate governance, thus, their roles need to be further developed. However, for this to happen, public accountants need to possess adequate skills and experiences. Moreover, as a very promising profession, public accounting is an area that is much required by the many companies striving to compete at the AEC 2015.

In tracing the profession, it can be said that the Public Accounting Profession in Indonesia is smaller in quantity when compared to other ASEAN countries. The Data Development Center of Public Accountants and Appraisal Services (PPAJP), Ministry of Finance, Indonesia, in their report of February 13, 2014, place the number of Public Accounting Firms (KAP) registered in Indonesia as 961 KAP with only 383 KAP active and others with records showing that they have been disbanded or have invalid permits. Moreover, majority of these public accounting firms are located in the Greater Jakarta area, thus very city based. Although the total population of Indonesia is around 250 million people, it seems ironic that its economic conditions are not conducive for growth. In this regard, Indonesia has to strive harder in order to be able to compete in the ASEAN Economic Community (AEC 2015).

This issue is a major challenge for accounting students in the country who are also prospective successors to the nation's development. With this in mind, the current study's objective is to examine how accounting students' perceptions of the public accounting profession are taken into account in facing he AEC 2015.

\section{Theoretical Review}

\subsection{Perception}

Perception is a cognitive process that allows a person to be able to interpret and understand the surrounding environment (Kreitner, 2005). Perception is also the experience of objects or relationships obtained by concluding information and interpreting the message. Nonetheless, because the perception of an object or event relies on a framework of space and time such a perception would be highly subjective and situational. Perception is determined by functional and structural factors. Functional factors are derived from needs, past experiences and other things. Therefore, what determines the perception is not the type or form of stimuli, but the characteristics of people who respond to such a stimuli. Structural factors are derived from the physical properties and the impact of the nerve inflicted on the nervous system of the individual.

According to Robbins (2009) "perception is the process by which individuals organize and interpret their sensory impressions in order to give the AEC 2015 to their environment". However, what is acceptable to someone could basically be different from objective reality. Although this should not exist, these differences often arise.

\subsubsection{Factors That Affect Perception}

Aprilyan (2011) suggests there are factors from outside and from within that influence the perceptions of human beings and they are as follows: 
Mirna Dianita and Niki Hadian 
1. External factors or from outside:

a. Concreteness that forms or abstract ideas that are difficult to be perceived and compared to that objective;

b. Novelty or new ideas, usually more attractive to the perception when compared to new things;

c. Velocity or acceleration, rapid movements that stimulate the emergence of perception more effectively when compared to slow movements;

d. Conditioned stimuli, such stimuli on conditioning your doorbell, ringing phones and others.

2. Internal factors or from within:

a. Motivation such as feeling tired but yet stimulated to respond to a break;

b. Interest or things that becomes more interesting when noted from the unattractive angle;

c. Need such as the need for certain things to be the center of attention

d. Assumptions such as thoughts we think of a situation can also affect our perception according to our experience of seeing, feeling and others.

On top of these factors, Robbins (2009) has also suggested that a number of factors operate to form and sometimes change our perceptions. These factors can be located in the perception of self-forming, inside objects or targets defined, or in the context of a situation where the perception was created.

\subsection{Accounting Students}

The Accounting Program is a program of study that produces accounting graduates who are ready to become competent and professional accountants and they are equipped with insight based managerial thinking. In order to graduate to become a professional and competent accountant in this globalized era, the students must be equipped with the right skills, knowledge, and character. In addition, for self-sustainable development, the students will also need to be equipped with the ability to do research that can be used for the development of science so as to achieve a higher level of education.

\subsection{Asian Economic Community 2015}

The ASEAN Economic Community (AEC) 2015 is an ASEAN economic integration that was created in the face of free trade between ASEAN countries. All the ASEAN countries have agreed to this agreement. The AEC 2015 was designed so as to realize the ASEAN insights of 2020. In the face of very tough competition experienced by countries in the AEC 2015, all countries involved must prepare themselves by developing their human resources (HR) to become skilled, intelligent, and competitive.

According to the ASEAN.org, the AEC 2015 is the goal of regional integration economy in Southeast Asia. It was enacted in 2015 with characteristics that include: (1) a single market and production, (2) a highly competitive economic region, (3) a region of equitable economic development, and (4) a region that is integrated in global economy.

\subsection{Public Accountant (Auditor)}

Aprilyan (2011) defines Public Accounting as "Professional accountants who sell services to the public, especially the field of examination of financial statements made by clients. The examination is mainly intended to meet the needs of creditors, investors, potential creditors, potential investors, and government agencies (especially tax authorities). Besides, the Certified Public Accountant also sells other services to the community such as tax consultations, management consulting, the make-up of accounting systems, and as compilers of financial statements". 


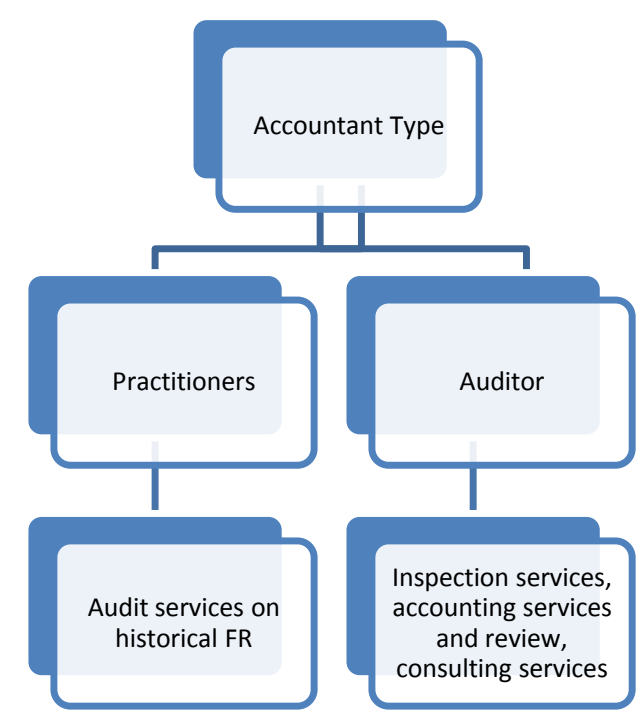

Figure 1. Ilustrate relations accountants, public accountants and auditors based on types Source: Mulyadi dan Puradireja (1998)

\subsection{Conceptual Framework}

\begin{tabular}{|c|c|c|}
\hline $\begin{array}{c}\text { Accounting } \\
\text { Student's } \\
\text { Perception }\end{array}$ & $\begin{array}{c}\text { Public } \\
\text { Accounting } \\
\text { Profession }\end{array}$ \\
\cline { 2 - 3 }
\end{tabular}

Figure 2. Conceptual Framework of this research

\section{Research Methodology}

As mentioned earlier, this study is qualitative in nature thus, data analysis will be descriptive. A questionnaire was distributed to accounting students to know about their perceptions of AEC 2015.

The sampling technique is a non-probability sampling technique that selects respondents based on a certain basic consideration. In this case, they must already know about the AEC 2015 and are studying in the public accounting profession. At the beginning of data collection, questionnaires were spread out to 300 respondents but only 288 questionnaires were returned. Of this, only 57 respondents (20\%) were able to answer all the questions, suggesting that the number of respondents who were aware of the AEC 2015 was small. To expand on the collection, another 300 questionnaires were deployed. The second time round, the emphasis was for accounting students to know about the implementations of the AEC 2015. Of the 300 questionnaires distributed, 282 completed the questionnaires. The final results thus obtained a total of 339 questionnaires that met the criteria for processing.

\section{Results}

Based on the study, it is deduced that only $20 \%$ of the accounting students were aware of the existence of the AEC 2015. In other words, there were still many accounting students who do not know and understand the 
implementation of the AEC 2015 and the effect it has on the profession of Certified Public Accountants. If many students, as a representation of the well-educated category of citizens, are still vague about the AEC 2015 , it would mean that the overall society of the country, would be even less informed. This deduction was derived because the Indonesian government is still lacking in the socialization and implementation of the AEC 2015 in terms of disseminating the information to the public. This seems to be the most difficult challenge for the Indonesian government as decision-makers in implementing the state policy for the welfare of the people.

Of the total respondents, more than half or $58.40 \%$ were women. Although most respondent's perceptions of themselves as an active student and as very active in the organization, both within the campus and in the external environment, it appears that $62 \%$ of the respondents were quite satisfied with the results of their study. Other related activities of the accounting students such as accessing information about accounting were reported by $47.8 \%$ who mentioned that they often or very often access information.

\subsection{AEC 2015 \& Response Knowledge of Respondents}

As mentioned above, not all the 339 respondents had in-depth understanding of the AEC 2015. Majority of the respondents (27.4\%) understood that the implementation of the AEC 2015 will create a free flow of goods and services but $72.6 \%$ of the respondents only understood the AEC 2015 as a condition creating a free flow of goods and services with public accountants acting as professional labor and capital.

Respondents used a variety of resources to obtain information about the AEC 2015. A total of 18 respondents acquired information only through the newspapers, 21 respondents acquired information through the television, 3 respondents acquired information through the radio, 66 respondents acquired information via the internet and only 6 respondents acquired information through lectures alone. This means that through lectures accounting students can also obtain more detailed information about their challenges in the public accounting profession.

Apart from the 114 respondents who obtained their information only from one source, as many as 144 people had obtained information from two or more sources at the same time. In this regard, 69 respondents had obtained information from three different sources at once. Only 12 respondents had obtained information from four sources simultaneously. In this regard, it appears that the television plays an important role, acting as the main source of information referred to by 141 respondents. A total of 87 respondents used the newspaper, 66 used the internet, 30 from the college they attend and 15 from radios.

Most respondents (63.7\%) agreed with the implementation of the AEC 2015. They argued that the creation of the AEC 2015 will promote the role of the public accounting profession and bring about a positive impact on the public accounting profession. Some of the reasons expressed by the respondents include:

(1) the public accounting profession in Indonesia is ready to compete with other public accountants in ASEAN countries;

(2) larger field of work;

(3) improving the competitiveness of Indonesian public accountants in the world;

(4) maximising the potential of the public accounting profession in Indonesia; and

(5) strengthening relationships between ASEAN countries.

When viewed from the liveliness of the association, the rejection of the AEC 2015 had come mostly from respondents who were active in organizations. This is because respondents who were active in organizations tend to be more active in seeking information related to government policies and they too like to criticize. Some of the active respondents had claimed that the Indonesian government had not been doing well enough in preparing its human resources to face the AEC 2015. They claim that this needs to be increased. 


\subsubsection{Reasons for wanting to work in the ASEAN countries}

There were a number of reasons that could make public accountants choose to work in other ASEAN countries (outside Indonesia). The first reason is the higher wages $(73.45 \%)$, the second reason could be their personal capacity or potency $(28.32 \%)$, the third reason could be the culture of the country concerned (19.47\%), the fourth reason could be the pressure regulation in the countries concerned (10.62\%) followed by other minor reasons $(3.54 \%)$.

In looking at the wage or salary, respondents were of the opinion that when working in the neighbouring country, their personal capacity (potential) will be fully utilized. Thus, the AEC 2015 will increase the respect, the rights and the responsibilities of workers. Another reason is that the culture of another ASEAN country is not too different from Indonesia hence, it will be easier for the accountants to adapt. In addition, the regulations that are applied by those ASEAN countries may probably not be too rigid as to protect the rights and security of its worker and citizens.

\subsection{Response to Compensation, Salaries and Professional Work Public Accountants in Indonesia}

Views regarding the competence of the Indonesian public accounting profession as compared to the public accounting profession of ASEAN countries can also be drawn from the results of the survey. Less than half $(40.7 \%)$ of the of the respondents were still undecided in deciding whether public accounting graduates in Indonesia are more competent than those from state universities of other ASEAN countries. This indecision of the respondents may be due to the absence of a standard benchmarking that could be used by the respondents in assessing the competence of public accountants.

According to the respondents' assessment of foreign public accountants, it appears that such skills possessed by foreign accountants would be better utilized in Indonesia than in their home country. Besides, it was noted that the cultural factors among the ASEAN countries are similar, thus, this can contribute to bringing public accountants from ASEAN countries to Indonesia. While the other reason is because the political stability of Indonesia could encourage public accountants from other ASEAN countries to come to Indonesia. Vice versa, public accountants in Indonesia may want to remain working in Indonesia because of Indonesia's economy which is better than the home country of foreign public accountants. The percentage of respondents saying this was $3.54 \%$. The same reason was also cited as the reason why public accountants may move form other ASEAN countries to Indonesia. With the increasing number of foreign public accountants who come to Indonesia, there would be more competition, so it can create more unemployment to local accountants. In line with this, $45.1 \%$ of the respondents agreed that the implementation of the AEC 2015 will lead to employment in the field of public accountants which then raises the difficulty to get a job.

Contrary to the fact that students still consider the competence of public accountants in Indonesia as equivalent to the competence of foreign public accountants, it was observed that the respondents mentioned that foreign public accountants may not always be better as competencies between the two can thus be compared.

With these conditions in view, can the Indonesian public accountant compete with foreign public accountants? About $41.6 \%$ of the respondents strongly agree that the competence of Indonesian public accountants is comparable to those of foreign public accountants. It appears that high confidence can be used as strength to compete later. However, high confidence is not good if it is not supported by real competence.

\subsection{Readiness to Face Challenges AEC 2015}

With regard to the competence accounting students have after graduation, $52.2 \%$ of respondents agreed that the competence of public accountants who graduated from Indonesia is still unable to compete with public accounting graduates from other ASEAN countries. Respondents felt that public accountants who had graduated from Indonesia may not have the ability to compete on the international situation. They mentioned 
that their current competence may not be able to meet the demands of international standards. A total of $16.8 \%$ of respondents rated that Indonesian accounting students can compete with other ASEAN graduates. This could be because their assessment was based on previous batch of accounting students who have had a lot of success and who held important positions in institutions or offices.

Majority of respondents (39.8\%) claimed they have the language competence to speak in English but when it came to writing in English, $47.8 \%$ claim that they have relatively good English skills. This claim certainly needs to be verified in view of the fact that orally, many of the students actually have a lesser ability. Nonetheless, most respondents $(34.5 \%)$ felt that there is a need to improve their speaking skills. They also felt that the international world of work today would require workers who can speak more than one international language.

In relation to the ability to master information technology, more than half (50.4\%) of respondents felt that they have the ability to master the technology.

When focusing on soft skill, most respondents rated themselves as having enough soft skills to compete with accounting graduates from ASEAN countries. With a variety of challenges to be faced by students and a list of competencies to develop, public accounting students in Indonesia have vocalised an idea of the kinds of working world which they would be faced with in the future.

\section{Conclusions and Recommendations}

\subsection{Conclusion}

From the survey conducted of 339 accounting students in Indonesia, the following conclusions can be drawn:

1. There are still many accounting students who do not know about the implementation of the AEC 2015. This is due to the lack of socialization provided by the government to the public. Most accounting students, however, do know about the AEC 2015 from information gained via the television.

2. Students who knew about the implementation of the AEC in 2015 also understood the implications they will face when choosing a profession such as a public accountant. However, the picture owned by the students about the impact of the implementation of the AEC 2015 is still very far from the truth. This is because they still lack information that should have been disseminated by the government to the Indonesian public accounting profession and foreign public accountants.

3. Students who knew about the implementation of the AEC 2015 also have the awareness to increase their competence as a public accountant in order to compete in the AEC 2015. Students have prepared to equip themselves in accordance with the demand standards of the world. However, students still do not have a picture in assessing their competence in comparison with foreign public accountants.

\subsection{Recommendations}

There are some recommendations that can be proposed for the benefit of future studies:

1. Given the accounting students' lack of knowledge about the implications of the AEC 2015 to the public, it is proposed that the accounting profession should disseminate the required information intensively and this can be done by various parties that are related to the students and the educational institutions. As is known, the student is an agent of change thus, increasing their competitiveness is a key factor in societal change.

2. Students who understand about the implementation of the AEC 2015 should have the awareness to increase their competence and this should be supported. For this reason, as well as for the university as a producer of highly educated labor force, it is expected that the country should make a greater emphasis to enhance the quality of graduates in accordance with the anticipated rising demands of the job market. 


\section{References}

Aprilyan, L. A., \& Laksito, H. (2011). Faktor-faktor yang Mempengaruhi Mahasiswa Akuntansi dalam Pemilihan Karir menjadi Akuntan Publik (Studi Empiris pada Mahasiswa Akuntansi UNDIP dan Mahasiswa Akuntansi UNIKA) (Doctoral dissertation, Universitas Diponegoro).

Danim, S. (2007). Metode Penelitian Untuk Ilmu-Ilmu Perilaku. Jakarta: Bumi Aksara.

Robert, K., \& Angelo, K. (2005). Organizational Behavior (Terjemahan) Buku 1. Edisi Kelima, Salemba Empat, Jakarta. Mulyadi \& Puradiredja, K. (1998). Auditing, (5th Ed.), Jakarta, Salemba Empat

Robbins, S. P. \& Timothy A J. (2009). Organizational Behavior. (12th Ed.)

Sukandarrumidi. (2006). Metodologi Penelitian. Yogyakarta: Gadjah Mada University Press.

Sunyoto, D. (2011). Metodologi Penelitian Ekonomi Alat Statistik \& Analisis Output Komputer untuk Mahasiswa dan Praktisi. Yogyakarta: CAPS.

Sunyoto, D. (2011). Praktik SPSS Untuk Kasus. Yogyakarta: MuliaMedika. 